\title{
混成堤ケーソン港内側に作用する越流津波 による波力と転倒防止策に関する研究
}

\author{
中村 友昭 1 - 峯浦 亮 2 澤 祐太朗 3 -水谷 法美 4 - 小竹 康夫 5 \\ 1正会員 名古屋大学准教授 大学院工学研究科社会基盤工学専攻（广464-8603 名古屋市千種区不老町） \\ E-mail: tnakamura@nagoya-u.jp \\ 2学生会員 名古屋大学大学院工学研究科社会基盤工学専攻（同上） \\ E-mail: kobe27mineura@gmail.com \\ 3学生会員 名古屋大学大学院工学研究科社会基盤工学専攻（同上） \\ E-mail: sut_arouwamp@yahoo.co.jp \\ 4フェロー 名古屋大学教授 大学院工学研究科社会基盤工学専攻（同上） \\ E-mail: mizutani@civil.nagoya-u.ac.jp \\ 5 正会員＼cjkstart東洋建設株式会社＼cjkstart鳴尾研究所（†663-8142 兵庫県西宮市鳴尾浜1-25-1） \\ E-mail: kotake-yasuo@toyo-const.co.jp
}

\begin{abstract}
津波越流時に混成堤ケーソンの港内側の面に作用する波力の特性と, 津波の越流によるケーソンの転倒 を防止する対策の効果を現地スケールの数值解析により考究した．その結果，ケーソンの港内側の面に作 用寸る波力は，港内の水位変動から静水圧を仮定して求めた波力に対して低減する現象がみられ，その低 減率は相対越流水深の増加とともに上昇寸る傾向を確認した。 また，この傾向に与えるマウンドの透水性 の影響がみられたことから，波力を検討する際におけるマウンドの透水性の重要性を示した．さらに，ケ ーソンの転倒防止効果を有する上部コンクリートの港内側の形状があることを確認した．このとき，潮位 の影響も考慮して発生する渦の規模を非常に小さく抑えられるような形状とすることで，ケーソンの転倒 を防げる粘り強い構造となる可能性が示唆された.
\end{abstract}

Key Words : tsunami, caisson, wave force, permeability, overturning, countermeasure, vortex

\section{1. 緒言}

東北地方太平洋沖地震津波での防波堤や防潮堤などの 海岸保全施設の被災を受けて，被災機構の解明とそれを 踏まえた粘り強い構造の開発が急務とされている．ケー ソン式混成堤の被災機構に関しては，有川ら吕2)小竹 らふ44な゙によって，津波が越流する際に，ケーソンの 港外側では波圧が静水圧より若干増加し，逆に港内側で は静水圧より若干減少することでケーソンに作用する水 平力が増大寸る現象が確認されている. また，この港内 側でみられる波圧の増加が抑えられる現象は，ケーソン 上を越流した流れの剥離に起因し，発生した渦の渦度の 大きさで評価できることが明らかとなっている5の。，さ らに，この被災要因を踏まえて，ケーソンの上部コンク リートの港内側の形状を斜面にする対策やケーソンの港 外側に係留索を設置する対策が提案されているわ。 しか し，これらの研究では，津波や潮位などの条件が限られ
ており十分な検討が行われているとは言えない. 本研究では，津波の越流による混成堤ケーソンの転倒 現象を対象に検討を行っている小竹ら出の水理実験との 比較により妥当性が確認されている数值計算モデル8)を 使用して，釜石港湾防波堤の規模を想定して上述の水理 実験を現地スケールにした計算を行う。そして, 津波, 潮位，マウンドの透水性の条件を多様に変化させた数值 実験を行うことで，ケーソンの港内側の面に作用する波 力の特性と転倒防止策の効果を考究する.

\section{2. 数値計算モデルの概要}

数值計算モデル8タ, メインソルバーと 3 つのモジュ 一ルから構成されている，メインソルバーは，透過性材 料の間隙内部の流体を含む非圧縮性粘性流体からなる全 気液相の流体運動を可動構造物の運動と地形の変化を考 


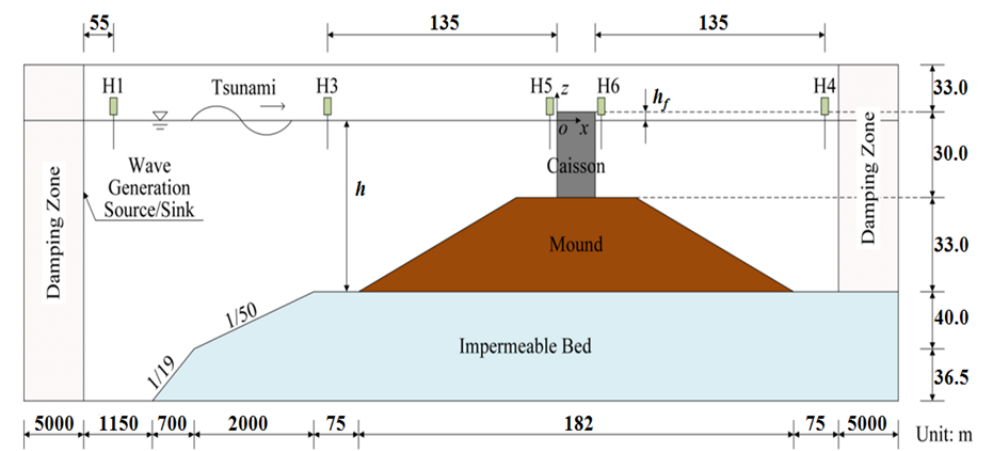

(a) 計算領域全体と水位計測位置

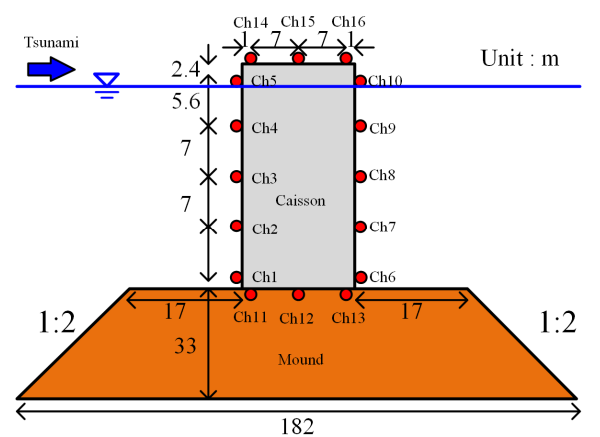

(b) 混成堤周辺

図-1 計算領域の概略図

慮して解析する連続式と Navier-Stokes 方程式に基づく LES (Large-Eddy Simulation) である. そのメインソルバ 一には，気液界面を追跡する MARS（Multi-Interface Advection and Reconstruction Solver）に基づく VOF（Volume of Fluid）モジュール，可動構造物を取り扱う体積力型 IB

(Immersed Boundary）法に基づく IB モジュール，掃流 砂・浮遊砂輸送による地形変化の計算と浮遊砂濃度分布 の解析を行う底質輸送モジュールが流体・構造・地形変 化の相互作用を解析できるように Two-Way カップリン グ手法により組み込まれている.ただし，本論では地形 の変化は対象としないことから，底質輸送モジュールは 使用しなかった。モデルの詳細は中村・水谷8)を参照さ れたい. なお，本現象に対するモデルの妥当性について は中村ららによって検証されており，津波による水位， 水圧, ケーソンの転倒挙動に関して水理実験結果をよく 再現できることが確認されている.

\section{3. ケーソンの港内側の面に作用する波力の特性}

\section{(1) 計算条件}

釜石港湾防波堤の北堤深部 3 区の規模を想定して，小 竹ら4の水理実験を Froude の相似則に基づいて 100 倍し た図-1 に示す現地スケールの計算領域を用いて解析を 行った. 同図に示すように，1/19 勾配の斜面，1/50 勾配 の斜面，水平床を順に設定し，その水平床上に約 $10 \mathrm{~kg} /$ 個を想定した中央粒径 $d_{50}=0.2 \mathrm{~m}$ の捨石からなるマウン ド（天端幅 $50.0 \mathrm{~m}$, 高さ $33.0 \mathrm{~m}$, 空隙率 0.3）とケーソン （高さ $30.0 \mathrm{~m}$, 幅 $16.0 \mathrm{~m}$, 密度 $1.85 \times 10^{3} \mathrm{~kg} / \mathrm{m}^{3}$ ) を固定 した. そして，波高 $H_{i}=6.20 \sim 15.00 \mathrm{~m}$ ，周期 $T=200 \sim$ $350 \mathrm{~s}$, 水平床上の静水深 $h=58.0 \sim 62.0 \mathrm{~m}$ の範囲で変化さ せた 30 ケースの引き波初動の長周期波を作用させた. このうち, $H_{i}=10.26,12.60 \mathrm{~m}, T=200 \mathrm{~s}, h=60.0 \mathrm{~m}$ の 2 ケースについては，マウンドの中央粒径 $d_{50}$ を，透水性 なしを想定した $d_{50}=0.0 \mathrm{~m}$ から小竹ら 4 の水理実験を現地 スケールにした $d_{50}=4.0 \mathrm{~m}$ までの 7 パターン変化させた. 座標軸は, ケーソンの港外側の面を原点とする水平岸向

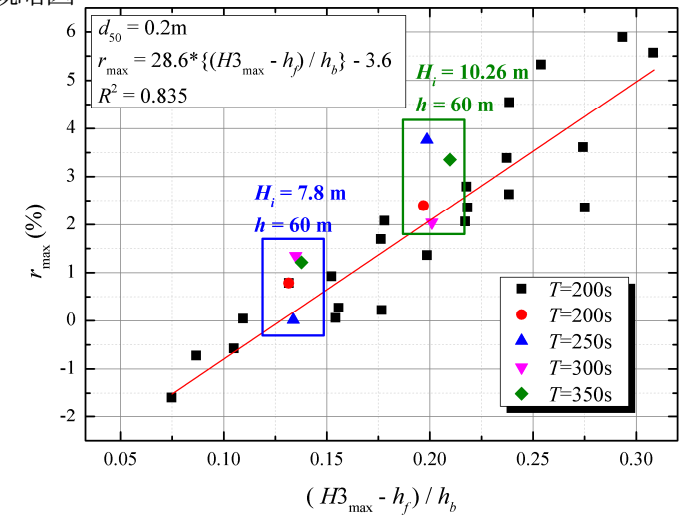

図-2 ケーソンの港内側の面に作用する波力の低減率 $r_{\text {max }}$ $\left(d_{50}=0.2 \mathrm{~m}\right)$

き座標を $x$ 軸, $h=60.0 \mathrm{~m}$ のときの静水面を原点とする鉛 直上向き座標を $z$ 軸とした。計算格子は，ケーソンの周 辺 $(-17.0 \leq x \leq 34.0 \mathrm{~m},-37.0 \leq z \leq 13.0 \mathrm{~m})$ に $1.0 \mathrm{~m} \times 1.0 \mathrm{~m}$ の等間隔格子を, それ以外の領域には不等間隔格子を用 いた．透水性に関するパラメータとして，付加質量係数 $C_{A}$ は- 0.04, 非線形抵抗力係数 $C_{D 1}$ は 0.45 , 線形抵抗力係 数 $C_{D 2}$ は 25.0 を用いた. その他のパラメータと境界条件 については中村ら5を参照されたい.

\section{（2）波力の特性}

ケーソンの港内側の面に作用する単位法線幅当たりの 波力 $F_{b n}$ に関して，中村らのと同様にケーソンから港内側 に若干離れた $\mathrm{H} 4$ での水位変動から静水圧を仮定して求 めた波力を $F_{b a, H 4}$ としたとき, $F_{b a, H 4}$ の最大值 $F_{b a, H 4}^{\max }$ に対 する $F_{b n}$ の最大值 $F_{b n}^{\max }$ の低減率 $r_{\max }$ を

$$
r_{\max }=\frac{F_{b a, H 4}^{\max }-F_{b n}^{\max }}{F_{b a, H 4}^{\max }} \times 100
$$

と定義する. なお， $F_{b a, H 4}$ と $F_{b n}$ には位相に差があること から，それぞれの最大值から $r_{\max }$ を求めた。また，H4 を含む $x \geq 100.0 \mathrm{~m}$ の範囲では水位変動の最大值の分布は ほぼ一様であり， $x \geq 100.0 \mathrm{~m}$ の範囲内であれば $\mathrm{H} 4$ の位 置が $r_{\text {max }}$ に与える影響は小さいことを確認している.

図-2 に，マウンドの中央粒径 $d_{50}=0.20 \mathrm{~m}$ のときの $r_{\max }$ と相対越流水深 $\left(H 3_{\text {max }}-h_{f}\right) / h_{b}$ の関係を示す. ここで, $H 3_{\max }$ はケーソンから港外側に若干離れた $\mathrm{H} 3$ での水位変 


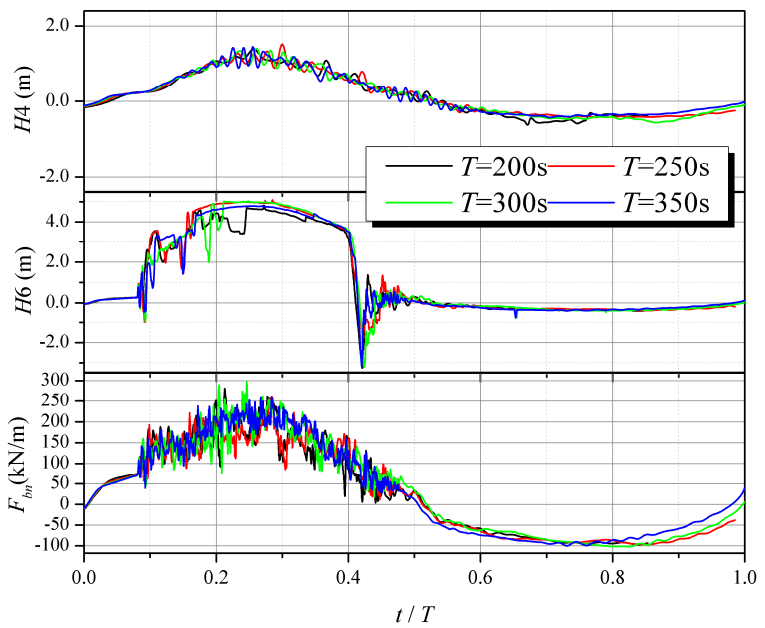

図-3 H4 での水位変動 H4, H6 での水位変動 H6, ケーソンの 港内側の面に作用寸る波力 $F_{b n}$ の時間変化に与える周期 $T$ の影響 $\left(H_{i}=10.26 \mathrm{~m}, h=60.0 \mathrm{~m}, d_{50}=0.2 \mathrm{~m}\right)$

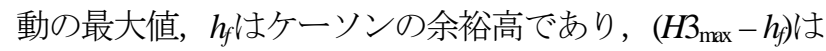
ケーソンの港外側の面で完全反射するとしたときの越流 水深を表す．また，有川ら22を参考に，ケーソンの下面 から H4での最大水位までの距離 $h_{b}$ で無次元化した. な お， $h_{b}$ はケーソンの高さを上限值とした。

周期 $T=200 \mathrm{~s}$ のとき, 図-2 より, 相対越流水深 $\left(H 3_{\text {max }}\right.$ $-h_{f} / h_{b}$ の増加とともに低減率 $r_{\text {max }}$ も増加寸る傾向が確認 できる，上述したように，波力の低減はケーソン上を越 流した流れの剥離に起因し，発生した渦の渦度の大きさ で評価できることが確認されている5の。．したがって， $\left(H 3_{\max }-h_{f}\right) / h_{b}$ の増加とともに越流の規模が大きくなり, 流れの剥離に伴う圧力の低下も大きくなったことから $r_{\text {max }}$ も増加したと推測され, この $r_{\text {max }}$ の増加は発生した 渦の渦度の大きさで評価できると考えられる.また，図 -2 より, $\left(H 3_{\max }-h_{f}\right) / h_{b}=0.3$ のとき $r_{\max }$ は 5\%程度となっ ており, 軸の定義が若干異なっているものの, 有川ら²) の実験スケールの結果との対応が確認できる. ここで, $T=200 \mathrm{~s} の$ 結果に対して近似式を求めると,

$$
r_{\max }=28.6 \frac{H 3_{\max }-h_{f}}{h_{b}}-3.6
$$

となる. したがって，ケーソンの港外側と港内側に生じ る最大水位が平面 2 次元計算などから得られれば，式(2) によりケーソンの港内側の面に作用寸る波力の低減率 $r_{\max }$ が簡便に推定できる. なお，図-2 より， $\left(H 3_{\max }-h_{f}\right) /$ $h_{b}$ が小さいときは, $r_{\max }$ が負值となっている. 具体的に は, 式(2)より, $\left(H 3_{\max }-h_{f}\right) / h_{b}$ が 0.13 を下回ると, $r_{\max }<0$ となることが分かる. このとき, 越流の規模が小さく, 流れの剥離に伴う圧力の低下も小さかったと推測される. その一方で，ケーソンのすぐ港内側の位置で生じた局所 的な水位の上昇の影響を受けたと推測されることから， 上述したように $r_{\text {max }}$ が負になったと考えられる. また, 式(2)は有川ら2)や宮田ら9)の結果から判断すると $\left(H 3_{\text {max }}-\right.$

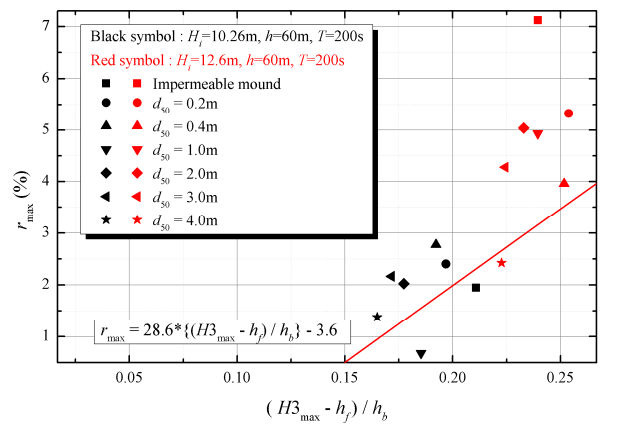

図-4 ケーソンの港内側の面に作用する波力の低減率 $r_{\max }$ に 与えるマウンドの透水性の影響

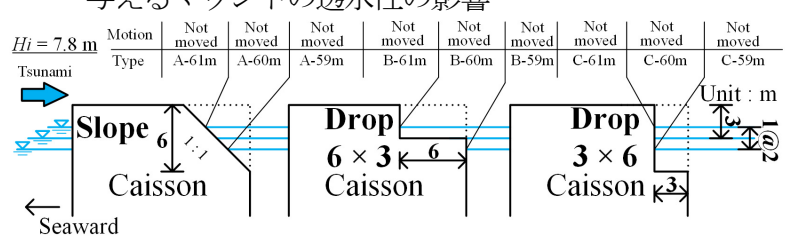

(a) $H_{i}=7.8 \mathrm{~m}$

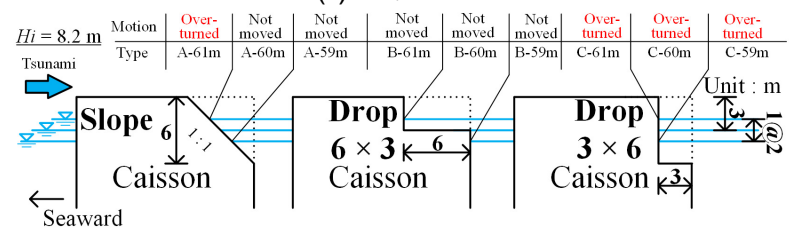

(b) $H_{i}=8.2 \mathrm{~m}$

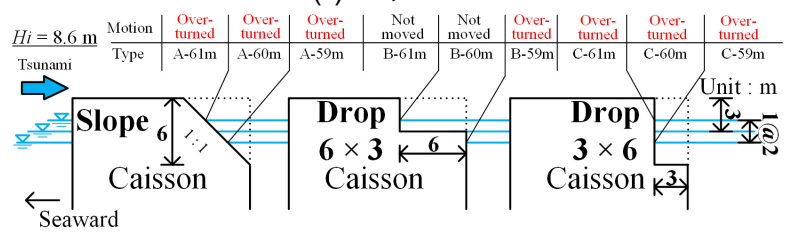

(c) $H_{i}=8.6 \mathrm{~m}$

図-5 ケーソン上部の概略図とケーソンの挙動

$\left.h_{f}\right) / h_{b}>0.3$ にも適用できると推測されるものの, 式(2)の 適用範囲については検討の余地を残している.

また, 図-2 より, 波高 $H_{i}$ や静水深 $h$ が同一の条件で も，周期 $T$ によって低減率 $r_{\text {max }}$ に若干のばらつきがみら れることが分かる. 図-3 に，H4 での水位変動 $\mathrm{H} 4, \mathrm{H} 6$ での水位変動 $H 6$, ケーソンの港内側の面に作用する単 位法線当たりの波力 $F_{b n}$ の時間変化に関して $T$ による 比較を例示する. なお，ケーソンの寸ぐ港外側の H5 の 位置での水位変動にゼロアップクロス法を適用して位相 を合わせた. 図-3 より，H4，H6，F $F_{b n}$ の波形に与える $T$ の影響は顕著には認められないことが分かる。ただし， $T=200,300 \mathrm{~s}$ のケースでは， $F_{b n}$ が瞬間的に増加する現 象が $t / T=0.20 \sim 0.25$ 付近に確認できる. そのため, それ らのケースでは $F_{b n}^{\max }$ が大きくなったことから, 図-2 に 示寸ように他のケースと比較して $r_{\text {max }}$ が若干小さくなっ たと考えられる. 図示しないが，同様の現象は， $H_{i}=7.8$ $\mathrm{m}, h=60.0 \mathrm{~m}, T=250 \mathrm{~s}$ のケースでも確認できた. この 一時的な $F_{b n}$ の増加のために $r_{\text {max }}$ に若干のばらつきがみ られるものの, 本研究の範囲では, $r_{\max }$ は $T$ によらず式 (2)により概ね評価できると考えられる.

図-4に低減率 $r_{\max }$ に与えるマウンドの透水性の影響を 

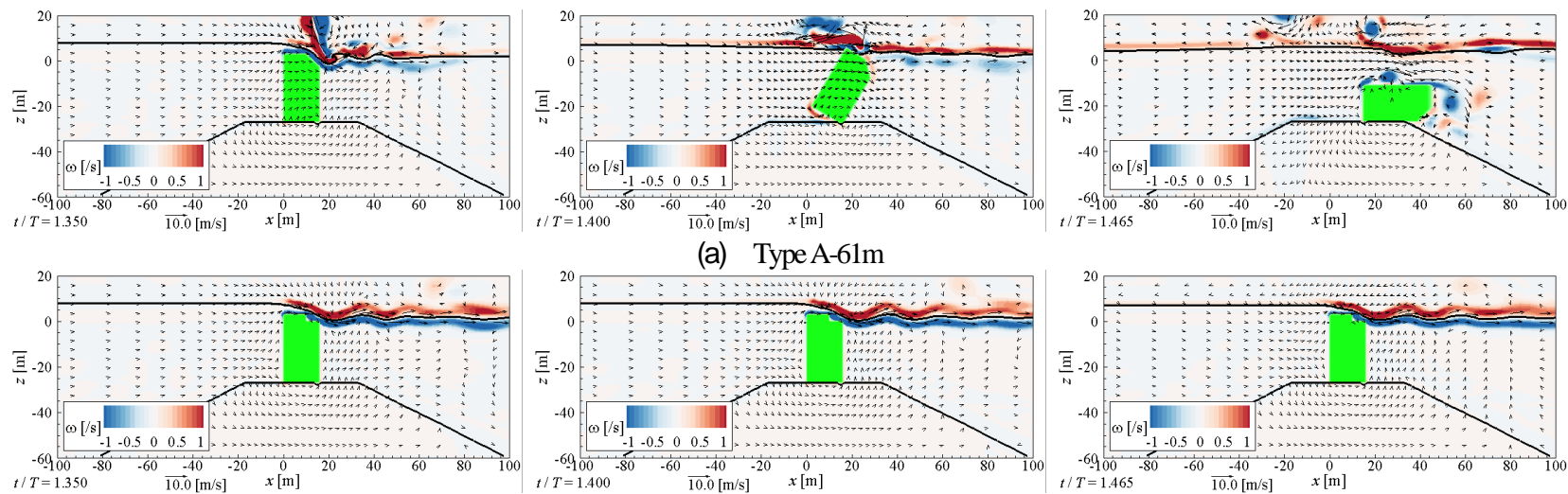

(a) Type A-61m
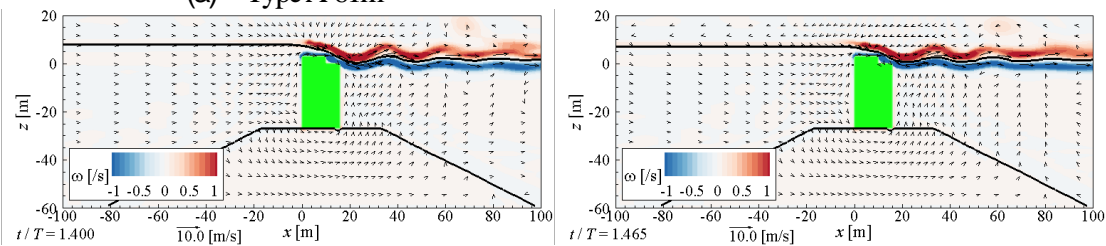

(b) Type B-61m

図-6 ケーソンの挙動の差異 $\left(H_{i}=8.2 \mathrm{~m}, T=200 \mathrm{~s}, h=61.0 \mathrm{~m}, d_{50}=0.2 \mathrm{~m}\right)$

示寸. 同図には, マウンドの中央粒径 $d_{50}=0.2 \mathrm{~m}$ に対す る式(2)も同時に示した．図-4より，d $d_{50}$ が大きくなり透 水性が上がるにつれて，全体的にプロットが左下へ移動 する傾向が確認できる．これは，マウンドの透水性が上 がると，港外側のH3での水位変動の最大值H3ma゙ 小さ くなり相対越流水深 $\left(H 3_{\max }-h_{f}\right) / h_{b}$ が減少するとともに, 港内側のH4での水位変動の最大值が大きくなり $r_{\text {max }}$ も減 少したためと考えられる. また，越流の規模が小さくな り，流れの剥離に伴う圧力の低下も小さくなったことも 影響していると推測される. したがって，波力の評価を 行う際には，マウンドの透水性を適切に設定することの 重要性が示唆される．ただし，マウンドの透水性が $r_{\text {max }}$ に与える影響を定量的に評価するまでには到っていない ことから，さらなる検討が不可欠である.

\section{4. ケーソンの転倒防止策の効果}

\section{(1) 計算条件}

ケーソンの転倒方止策として，図-5に示すように，中 村らクと同様に上部コンクリートの港内側の形状を斜面 に変更する対策（Type A）に加えて, 斜面として切り取 った部分と同面積の段落ちとする2種類の対策（Type B, C）を対象とした．そして，それらの対策を講じたケー ソンを中央粒径 $d_{50}=0.2 \mathrm{~m}$ 捨石からなるマウンドの上 に設置し，波高 $H_{i}=7.8 ， 8.2,8.6 \mathrm{~m}$, 周期 $T=200 \mathrm{~s}$, 静水 深 $h=59.0,60.0,61.0 \mathrm{~m}$ の9パターンの引き波初動の長周 期波を作用させた。ただし，上部コンクリートの形状が ケーソンの挙動に与える影響を検討するために，初期状 態でのケーソンの水中重量が矩形のケーソンと等しくな るようにケーソンの密度を調整した。 また，中村ららに おいてケーソンの転倒が再現できることが確認されてい ることから，マウンド天端のケーソン後趾の位置に長さ が2格子分，深さが1格子分の窪みを設けるとともに，マ ウンドとケーソンの静止摩擦係数 $\mu$ を 0.44 , 動摩擦係数 を 0.40 とした，なお，図-5にはケーソンの転倒の有無も

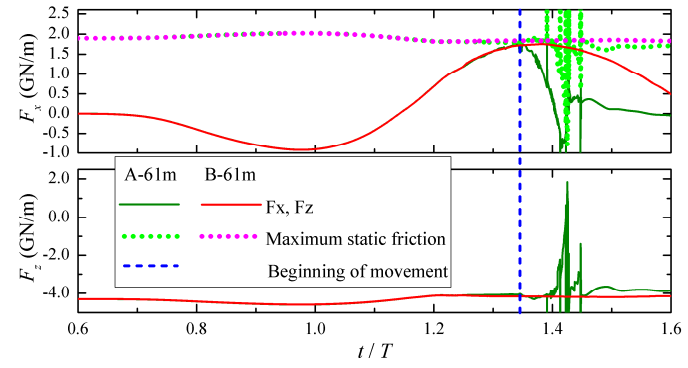

図-7 ケーソンに作用する水平力 $F_{x}$, 鉛直力 $F_{z}$, 最大静止摩 擦力の時間変化の差異 (図-6 と同ケース)

示したが，詳細は後述する.

\section{（2） ケーソンの挙動}

ケーソンの転倒方止策の効果を検討寸るために，ケー ソンを移動可能な状態とした解析を行った.

図-6に，波高 $H_{i}=8.2 \mathrm{~m}$, 静水深 $h=61.0 \mathrm{~m}$ のときのケー ソンの挙動を例示する. ここで, する渦度である. また, 図-7に, ケーソンに作用する単 位法線幅当たりの水平力 $F_{x}$ と鉛直力 $F_{z}$ の時間変化を示す.

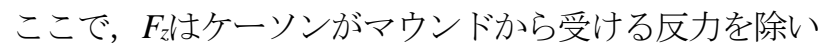

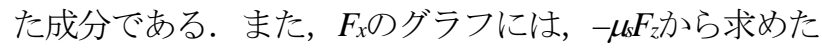
最大静止摩擦力も同時に示した.

図一より，Type A-61mの場合には対策実施後にもケー ソンに転倒が生じたものの, Type B-61mの場合にはケー ソンの転倒が抑えられたことが分かる。 このとき，図-7 に示寸ように， $t / T=1.3$ の少し前までは， $F_{x}, F_{z}$, 最大静 止摩擦力ともに転倒防止策による差は認められない。し かし，その後はType A-61mの方がType B-61mよりもFが 若干大きく, その影響を受けて最大静止摩擦力が若干小 さかったことが分かる. そのために，Type A-61mではFx が最大静止摩擦力を上回ったことを確認しており, 最終 的に図-6(a)に示寸ようにケーソンが後趾回りに回転し 転倒した. その一方で, Type B-61mの場合には，F F 大静止摩擦力に漸近しているものの上回らなかったこと を確認しており，そのために図-6(b)に示寸ようにケー ソンに転倒は生じなかった。

以上の結果として，ケーソンの転倒の有無をまとめた 

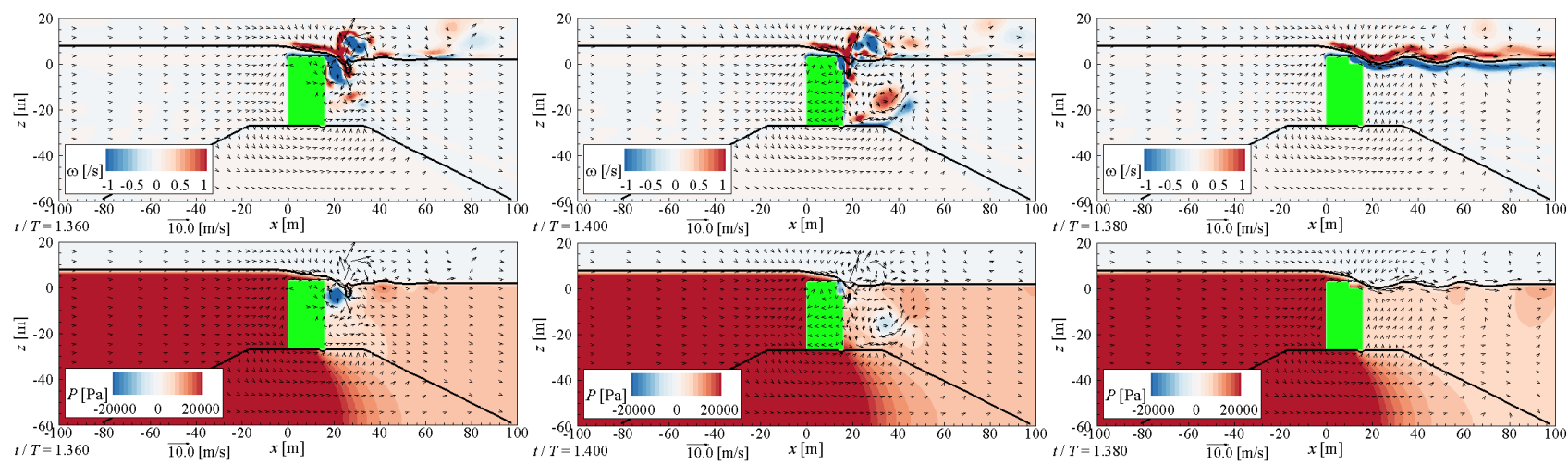

(a) 矩形厅ーソン

(b) 転倒時の例 (TypeC-61m)

(c) 非転倒時の例 (Type B-61m)

図-8 ケーソンに作用する水平力 $F_{x}$ が最大となる瞬間の渦度 $\omega$ と圧力変動 $P$ の分布 $\left(H_{i}=8.2 \mathrm{~m}, h=61.0 \mathrm{~m}\right.$; ケーソン固定時 $)$

図-5より，本研究の範囲では，Type B，Type A，Type C の順に転倒防止効果が高いことが分かる．また， $H_{i}=8.2$ mのType Aのうち $=61.0 \mathrm{~m}$ ときのみ, $H_{i}=8.6 \mathrm{~m} の$ Type Bのうち $=59.0 \mathrm{~m}$ ときのみにケーソンの転倒が生じた ことから，波高が同じであっても，Type Aの場合はケー ソンの天端から静水面までの高低差が小さくなると，ま たType BとType Cの場合は上部コンクリートの港内側の 水平部から静水面までの高低差が小さくなると, 転倒防 止策の効果が低下寸る可能性が示唆される. したがって, 上部コンクリートの形状を決定するに際して，潮位の影 響も考慮に入れて検討を行う必要性が示唆される.

\section{(3) ケーソンの転倒機構}

ケーソンに転倒が生じないように固定し，その固定し たケーソンに波高 $H_{i}=8.2 \mathrm{~m}$ 津波を作用させて，ケーソ ンの挙動に差異が生じた要因を検討する.

図-8に，ケーソンに作用寸る水平力 $F_{x}$ が最大となった 瞬間の渦度 $\omega$ と圧力変動 $P$ の分布を示寸．ケーソンに転 倒が生じた場合には，図-8(a)と(b)に示すように，ケー ソン上を越流した流れによりケーソンの寸ぐ港内側に渦 が形成されていることが分かる，そのため，ケーソンの すぐ港内側での圧力の上昇が抑えられたことから，ケー ソンの港内側の面に作用する沖向きの波力の上昇も抑え られ，ケーソンの転倒に到ったと考えられる。一方，觉 ーソンに転倒が生じなかった場合には，図-8(c)に示す ように，渦は水面に沿って形成されていることが分かる. そのため，ケーソンの寸ぐ港内側での圧力の上昇と，そ れに伴うケーソンの港内側の面に作用する沖向きの波力 の上昇は上記のケースほどは抑えられていなかったこと から，ケーソンの転倒には到らなかったと考えられる.

そこで，この波力の低減は発生した渦の渦度の大きさ で評価できることが確認されていることからの，ケーソ ンの港内側の面のうち，上部コンクリートの形状を変更 した影響を受けない天端から $8.0 \mathrm{~m}$ 下Ch 9 (図-1(b)参 照）の位置に生じる渦度 $\omega$ chに着目した。 図-9に， $F_{x} の$

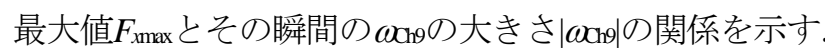

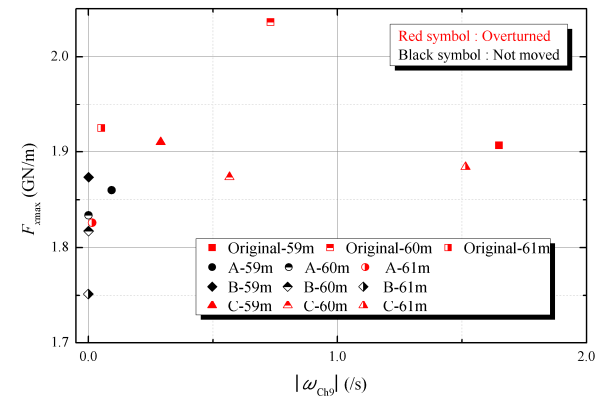

図-9 ケーソンに作用寸る最大水平力 $F_{x \text { max }}$ とその瞬間の渦度 の大きさ $|\omega c h|$ の比較（ $H_{i}=8.2 \mathrm{~m}$; ケーソン固定時 $)$

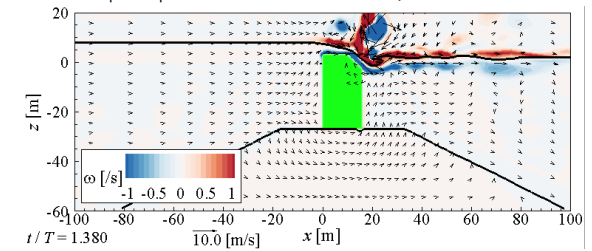

図-10 ケーソンに作用する水平力 $F_{x}$ が最大となる瞬間の渦 度 $\omega$ の分布 (Type A-61m; $H_{i}=8.2 \mathrm{~m}, h=61.0 \mathrm{~m}$; ケー ソン固定時)

ここで, Originalは対策未実施の矩形のケーソンを表す.

図-9より，| $\mid 0$ ch $\mid$ |゙非常に小さいときにはF $F_{\text {xmax }}$ 小さく 抑えられる傾向があり，上部コンクリートの形状を適切 に変更することでケーソンの転倒が生じにくくなってい ることが分かる．ただし，図-9に示すように，Type A$61 \mathrm{~m}$ 場合には，| $|\omega c h|$ やF $F_{\text {xmax }}$ が小さく抑えられているに も関わらず，ケーソンに転倒が生じている．このときの 渦度 $\omega$ の分布を図-10に示寸．同図と図-8の比較より， $\omega$ の分布に関しては，ケーソンに転倒が生じなかった場合

(図-8(c)）との類似が確認できる，そのため，図-7に示 したようにType A-61mとType B-61mでF作差は認められ なかったと考えられる．その一方で，上述したように， F はType A-61mの方が若干大きく，そのために最大静止 摩擦力が若干小さかったことから，Fxの差は小さいもの の，ケーソンの転倒に到っている.

以上より，発生する渦の規模を非常に小さく抑えられ るように上部コンクリートの形状を決定することで， ケ ーソンの転倒を防ぐことができ粘り強い構造となること が示唆される．ただし，ケーソンに作用する鉛直力の差 でケーソンの転倒の有無が決まるときには，上部コンク 
リートの形状の効果は渦の規模では説明できないことか

ら，この場合の評価には課題を残している.

\section{5. 結論}

本研究では, 津波越流時にケーソンの港内側の面に作 用する波力の特性と，津波の越流によるケーソンの転倒 を防止する対策の効果を現地スケールの数值解析により 考究した. その結果，得られた結論を以下にまとめる.

1. ケーソンの港内側の面に作用寸る波力は，ケー ソンの港内側の水位変動から静水圧を仮定して 求めた波力に対して低減する現象がみられ，そ の低減率は相対越流水深の増加とともに上昇寸 る傾向を示した．また，その傾向に与える周期 の影響は小さいことを確認した，その一方で， マウンドの透水性の影響はみられたことから， 波力の評価を行う際にマウンドの透水性を適切 に設定することの重要性が示唆された。

2. ケーソンの転倒防止効果を有する上部コンクリ ートの港内側の形状があることを確認した．た だし，その効果は波高だけではなく潮位の影響 も受けることが判明した．また，ケーソンの港 内側に生じる渦の規模を非常に小さく抑えられ れば，ケーソンに作用する水平力も低減でき， 転倒が生じにくくなることを確認した。したが って，潮位の影響も考慮して渦の規模を非常に 小さく抑えられるように上部コンクリートの形 状を決定することで，ケーソンの転倒を防げる 粘り強い構造となることが示唆された.

謝辞 : 本研究は科学研究費補助金基盤研究(A)（代表 : 水谷法美）の補助を受けたことを付記し，謝意を表する.

\section{参考文献}

1) 有川太郎, 佐藤昌治, 下迫健一郎, 富田孝史, 辰巳 大介, 廉 慶善, 高橋研也：釜石湾口防波堤の津波 による被災メカニズムの検討一水理特性を中心とし た第一報一，港空研資料，No. 1251， 52 p., 2012.

2) 有川太郎, 佐藤昌治, 下迫健一郎, 長谷川 厳, 稲 垣茂樹, 佐藤正勝, 下澤 治：東日本大震災におけ る釜石湾口防波堤の被災メカニズムに関する研究, 土木学会論文集 B2（海岸工学）, Vol. 68, No. 2, pp. I_826-I_830, 2012.

3) 小竹康夫, 松村章子, 山野貴司, 金澤 剛, 荒木進 歩：天端を越流する津波が防波堤の安定性に与える 影響について, 土木学会論文集 B2（海岸工学）, Vol.67, No. 2, pp. I_766-I_770, 2011.

4) 小竹康夫, 荒木進歩, 松村章子：天端を越流する津 波が混成堤式防波堤のケーソン部に与える波圧特性 に関する実験的研究, 土木学会論文集 B3（海洋開 発）, Vol. 68, No. 2, pp. I_264-I_269, 2012.

5) 中村友昭, 安藤康平, 山田裕貴, 水谷法美, 小竹康 夫 : 津波の越流に伴う混成堤ケーソンの挙動とその 機構に関する数值解析, 土木学会論文集 B2（海岸工 学)，Vol. 68, No. 2, pp. I_831-I_835, 2012.

6) 中村友昭, 安藤康平, 水谷法美, 小竹康夫 : 津波の 越流による混成堤ケーソン岸側での水圧の低下機構 に関する研究, 土木学会論文集 B3（海洋開発）, Vol.69, No. 2, pp. I_389-I_394, 2013.

7) 中村友昭, 安藤康平, 水谷法美, 小竹康夫 : 津波の 越流による混成堤ケーソンの転倒防止策に関する研 究，土木学会論文集 B2（海岸工学）, Vol. 69, No. 2, pp. I_906-I_910, 2013

8) 中村友昭, 水谷法美 : 3 次元流体 - 構造 - 地形変化連 成数值計算モデルに基づく遡上津波による陸上構造 物周辺の局所洗掘現象に関する数值シミュレーショ ン, 第 24 回数值流体力学シンポジウム, E10-4, 9 p., 2010.

9) 宮田正史, 小竹康夫, 竹信正寛, 中村友昭, 水谷法 美, 浅井茂樹：防波堤を越流寸る津波の水理特性に 関する実験的研究，土木学会論文集B3（海洋開発）, Vol. 70, No. 2, 2014, 投稿中.

\title{
STUDY ON WAVE FORCE ACTING ON THE HARBOR SIDE OF A CAISSON DURING TSUNAMI OVERFLOW AND COUNTERMEASURES AGAINST THE OVERTURNING OF THE CAISSON
}

\author{
Tomoaki NAKAMURA, Ryo MINEURA, Yutaro SAWA, Norimi MIZUTANI \\ and Yasuo KOTAKE
}

Prototype-scale numerical analyses are carried out to investigate wave force acting on the harbor side of a caisson during tsunami overflow and effectiveness of countermeasures against overturning of the caisson. Numerical results show that the wave force acting on the harbor side of the caisson is overestimated by the force calculated from water surface elevation on an assumption of hydrostatic pressure, and its overestimation becomes large with an increase in a relative overflow height. This relationship is found to be affected by the permeability of the rubble mound, suggesting that the permeability of the rubble mound is essential when evaluating the wave force. Furthermore, it is revealed that there are effective configurations of the upper part of the caisson to prevent its overturning motion, and the effectiveness of the change in the configuration can be assessed using the scale of vortices. 